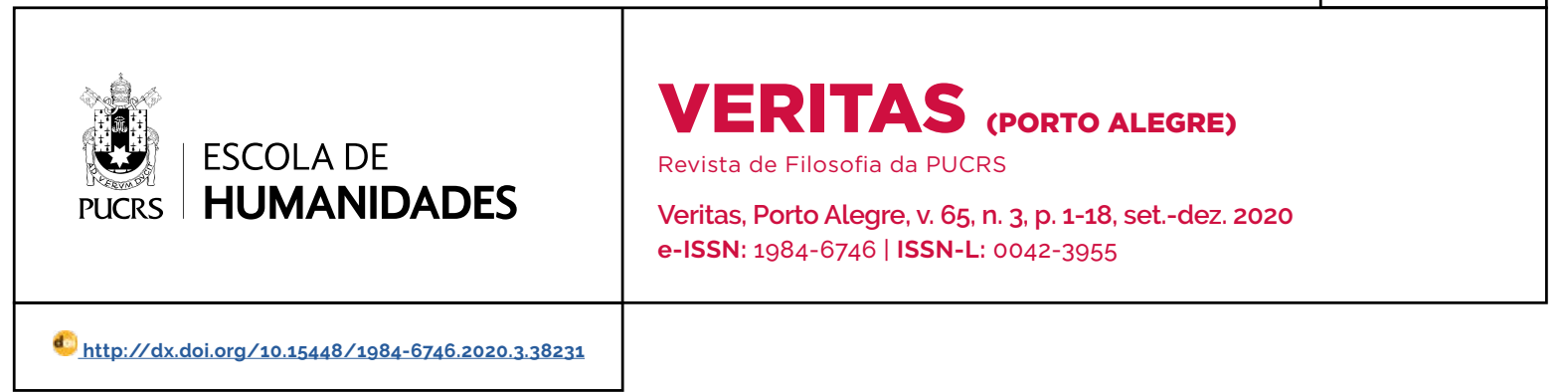

SEÇÃO VARIA

\title{
Youth Movements, Civil Disobedience, and the Skandalon of the Ecological Crisis
}

\author{
Movimentos juvenis, desobediência civil e o Skandalon da crise ecológica \\ Movimientos juveniles, desobediencia civil y el skandalon de la crisis ecológica
}

\section{Nuno Pereira \\ Castanheira $^{1}$}

orcid.org/0000-0002-2322-0343

npcastanheira@gmail.com

Received on: May $20^{\text {th }}, 2020$

Approved on: Aug. 01 1 st 2020

Published on: Jan. $12^{\text {nd }}, 2021$

\begin{abstract}
The ecological crisis is endangering life on Earth as we know it, giving rise to multiple protests, strikes and marches around the world, most of them lead by children and teenagers. The aim of this paper is to argue for the legitimacy of the presence of children and teenagers in political life in the current state of the ecological crisis through a seemingly paradoxical kind of participation: civil disobedience, i.e. refusal to participate. The paper will start by addressing the need to think the ecological crisis and analyze its origins; it will then consider the significance of the role performed by children and teenagers in the political stances regarding the crisis on the basis of Hannah Arendt's ontological-political thought. Keywords: Anthropocene. Hannah Arendt. Subjectification and desubjectification. Non-participation.
\end{abstract}

Resumo: A crise ecológica colocou em risco a vida na Terra tal como a conhecemos, originando múltiplos protestos, greves e marchas em todo o mundo, a maioria dos quais liderados por crianças e adolescentes. Este artigo pretende argumentar em favor da legitimidade da presença de crianças na vida política no estado atual da crise ecológica por via de um tipo aparentemente paradoxal de participação: a desobediência civil, isto é, a recusa em participar. O artigo começa por abordar a necessidade de pensar a crise ecológica e analisar as suas origens; depois considera o significado do papel desempenhado pelas crianças e adolescentes nos posicionamentos políticos relativos à crise com base no pensamento ontológico-político de Hannah Arendt.

Palavras-Chave: Antropoceno. Hannah Arendt. Subjetivação e dessubjetivação. Não-participação

Resumen: La crisis ecológica ha puesto en riesgo la vida en la Tierra tal como la conocemos, originando múltiples protestas, huelgas y marchas en todo el mundo, la mayoría de las cuales son dirigidas por niños y adolescentes. Este artículo pretende argumentar a favor de la legitimidad de la presencia de los niños en la vida política en el estado actual de la crisis ecológica a través de un tipo de participación aparentemente paradójica: la desobediencia civil, es decir, la negativa a participar. El artículo comenzará abordando la necesidad de pensar en la crisis ecológica y analizar sus origenes; luego considerará el significado del papel desempeñado por los niños y adolescentes en las posiciones politicas relacionadas con la crisis basándose en el pensamiento ontológico-político de Hannah Arendt. Palabras clave: Antropoceno. Hannah Arendt. Subjetivación y desubjetivación. No participación. 


\section{Introduction}

Human intervention on the Earth's ecosystems introduced changes whose pace is incompatible with natural restoration and re-balancing cycles, endangering life, as we know it, including the lives of future human generations. There have been repeated calls for attention on the impacts of this onslaught on nature, particularly since the 1960's. Consecutive assessments published by the United Nations, along with the introduction of the paradigm of Sustainable Development in international political agenda and policies in the late 1980's (DEVELOPMENT, 1987; UNITED NATIONS, 2012), were part of an attempt to address the issue. For over 30 years, political institutions at different levels have been trying to deal with this crisis, mostly through mitigating policies unable to introduce significant change into the status quo or by being straightforwardly remiss (EHLERS; KRAFFT, 2006; STEFFEN et al., 2018; UNITED NATIONS, 2015). In consequence, the stable conditions for life on Earth are endangered by human intervention in natural processes (STEFFEN et al., 2018). From significant losses in biodiversity to the transformation, degradation and even collapse of ecosystems, as well as global climate change and rise in sea temperatures (BARNOSKY et al., 2011; RIPPLE et al., 2017; UNITED NATIONS, 2019), the impact of human intervention on the Earth System has reached such a proportion that a discussion was set in motion regarding whether we are living in a new geological era, the Anthropocene (CLARK, 2015: CRUTZEN, 2002; MALM; HORNBORG, 2014; RAFFNS $\varnothing E, 2016)$. This new era projects itself into millennia and human beings are no longer mere spectators of its unpredictable developments, but rather its main driving factor (CRUTZEN, 2002).

The Anthropocene may be the scientific proof of Hannah Arendt's thesis that human beings have "[...] begun to act into nature [...]" (ARENDT, 1959, p. 231). Human action into nature unleashed unprecedented processes that are endangering the basic conditions of life on Earth as they are given to human beings. This is the new factual condition of human life. Meanwhile, society continues to operate according to standards, measures and conditions of the past, resorting to mass manipulation and organized lying if needed to sustain its way of living. ${ }^{2}$ Even the relatively new Green Economy risks suffering the same fate of Sustainable Development ${ }^{3}$, whose focus was redirected to the sustainability of economic growth and to financial instruments as the carbon emission trading market, reproducing the same old issues and inequities in new parlance. The Green Economy discourse will probably end up by subsuming nature under the same economicfinancial rationale, reducing it to natural capital, ultimately achieving its transformation into one big marketable commodity. ${ }^{4}$

Widespread indifference to the ecological crisis led to appeals by António Guterres, the United Nations Secretary-General, first to political leaders and then to young people, accusing older generations of being incapable of providing adequate answers to the issue. Guterres argued that young people have put themselves in position to face the challenge and therefore should be the ones driving the process of political and social transformation. With the climate strike movement in mind, Guterres stated: "[...] schoolchildren have grasped its urgency better than global leaders. They know the window of opportunity is closing;

\footnotetext{
2 On the efforts of some multinational corporations to minimize or deny the potential ecological consequences of their activities see, for example, (GLASER, 1982; JACOBS et al., 1988) According to Influence Map, "[...] the five largest publicly-traded oil and gas majors (ExxonMobil, Royal Dutch Shell, Chevron, BP and Total) have invested over \$1Bn of shareholder funds in the three years following the Paris Agreement on misleading climate-related branding and lobbying." ((INFLUENCEMAP, 2019, p. 2).

3 For criticism of the notion of Sustainable Development, see, for example, Castanheira (2017), Ferry (2007), Rolston (2012).

4 The Green Economy policy is riddled with ambiguities, pitfalls and presuppositions that are difficult to overcome (see (UNMÜSSIG: SACHS; FATHEUER, 2012)). Arguing for a reformist strategy in the economic transition from "brown" to "green" may seem strategically sensible (FERGUSON, 2015). However, it is misleading and misses the point. On the one hand, the pace of such a transition is much slower than the current pace of ecological depletion, as reported by the documents referenced above. On the other hand, the Green Economy seems to be grounded on general principles that are akin to those of the Sustainable Development policy, namely the imposition of the predominant neoliberal capitalist worldview on nature, with foreseeable results. It remains fundamentally business as usual covered by reformist, conscience appeasing, and historically blind rhetoric. The answer to the ecological crisis undoubtedly must include the economy, but is essentially political, demanding a radical reflection on and transformation of our way of living.
} 
they are determined to beat this threat and they are making a big difference already."(NATIONS, 2019a)

For the purposes of this essay, I will focus, first, on the ecological crisis itself and, second, on whether young people should be involved in political disputes concerning the issue.

Arendt views the participation of children in politics as a way of adults evading their responsibility for the world and toward children themselves (ARENDT, 2003). However, she was also stated, in reply to Günther Gaus' question about the reasons underlying her political work in pre-war Germany, that "If one is attacked as a Jew, one must defend oneself as a Jew" (ARENDT, 1994, p. 12) Would this principle be applicable to children and teenagers when their future is at stake? More precisely, would it be applicable if not only their capacity to begin anew is at stake, but more extremely the ontological fact of natality where it is rooted is endangered, along with the basic conditions of life on Earth sustaining it? If so, how to apply it?

First, the essay will present a brief account of what it might mean to think the ecological crisis. Then, it will address the ecological crisis, its meaning, the nexus of Modern experiences that make up its presupposed normative ground and the relation of the latter to the current ecological situation. Lastly, it will discuss the presence of children and teenagers in the public space in the current state of the ecological crisis, arguing for its legitimacy in the form of non-participation and non-violent civil disobedience.

\section{The Significance of Thinking the Ecological Crisis}

Human life is marked by alienation - humans are newcomers into a world that is essentially alien to them - and by understanding - the effort of dealing with alienation by constantly trying to find meaning and make the world its home. Understanding enables human life to be at home in the world, regardless of the transient and precarious character of the human being's sojourn in it (ARENDT, 1994). Although this essay in understanding always finds its origin in personal initiative - one inhabits an existence, a gap in time between being born and dying, which is ineradicably one's own -, it is a dialogical process involving others - otherness in general, others strictly speaking or "oneself as another" (RICOEUR, 1992). Others guarantee the reality of one's individual existence (being-of-the-world) by bearing witness to it (ARENDT, 1959).

To ask questions is an essential element of the thinking activity, characterized by the individual's temporary withdrawal from the world - temporary non-participation in the world's business -, and by the search for meaning for the fact of existing (ARENDT, 1978a). To ask questions is to implicitly acknowledge the limited or conditioned character of our understanding - of what we know, what we control, what we are - and to open ourselves to otherness, to different possibilities and potentialities, to a plurality of possible meanings - of what we know, what we control, what we are (HEIDEGGER, 1967, parag. 2-4). Asking questions is not only something human beings do, it is something human beings are, contributing to make their lives distinctively human. To be human is to become a question to oneself, humans are question-asking beings (ARENDT, 1978b, 2005, 2006a). While in search for meaning for an indeterminate, contingent existential condition - expressed in The Human Condition's purpose of thinking what we are doing (ARENDT, 1959) - , the human being finds itself as a participant in an open, shared space - the world or the public sphere - where it may begin anew. To ask questions is to become aware of the ontologically rooted fact of natality, of oneself as a beginning; it means to become aware of the potential plurality of ways of making freedom real and of one's meaningful existence, first and foremost, as political (ARENDT, 1973, p. 479).

In the context of the ecological crisis, to think what we are doing - to "[...] stop and think [...]"(ARENDT, 1978a, p. 175), to reconsider the meaning of our humanity - is a political task of the first order, as what we are doing has unprecedented and unpredictable consequences of existential and ontological import, a fact that is a clear indication of its urgency. 


\section{Ecological Crisis - Judgment, Ideology, and Givenness}

The ecological crisis is a crisis affecting the human ability to be at home in the world, of making both the world and the earthly condition human places of living, manifested in two complementary and interrelated ways: the environmental crisis and the socio-political, institutional crisis.

A crisis takes place when the standards, laws and measures of judgment inherited from the past to guide us through the predicaments of the present are no longer reliable (ARENDT, 2006a). However, the fact that all past measures and standards of judgment are no longer reliable for our understanding of the new, present conditions does not mean they are no longer enforced on our daily life; and therein lies the danger, since they may prevent us from experiencing reality as it is, without the veil of already known and established answers.

Following Kant (2000), Arendt identifies two kinds of judgment with two distinct functions: 1) to organize and subsume the particular and individual under a given general rule (Kant's determinant judgment) and; 2) to deal with events and situations for which there are no pre-existing standards of conduct capable of accounting for their unprecedented character, their newness (Kant's reflective or aesthetic judgment), which has, in Arendt, a pre-eminently political dimension due to its exemplary, communicative and persuasive nature (ARENDT, 1982).

Any crisis manifests and develops itself through insistence on resorting to determinant judgments - whose unquestioned sovereignty over events reduces the new to the already known - in unprecedented conditions that demand aestheticpolitical judgments capable of accounting for and embracing the exemplary character of the new without annihilating it as such. The ground of every determinant judgment is a prejudgment or prejudice. For Arendt, prejudices are something we share with others in everyday life and are considered self-evident by the group we belong to; they allow us to acknowledge and recognize our commonality and each other. Their function is to protect us and shield us from experiencing and judging anew all facets of reality. In fact, they are used as standards for judgment in everyday life, in a limited, non-binding context, forming the basis of public opinion of our partial ways of seeing the world. Since they lack legitimate experiential basis - they are not the result of currently experiencing an event, but of the reproduction of a judgment whose basis in experience is past -, they may, in extreme cases, prevent us from experiencing events and judging them in accordance with their own, new and unprecedented, conditions. The subsumption of something completely new to past prejudices unable to serve as guides for an understanding of the world we live in may ultimately result in loss of contact with facts and in the dilution of our own sense of reality, i.e. in alienation (ARENDT, 2005).

For Arendt, "[...] to understand is the human way of being alive [...]" (ARENDT, 1994, p. 308), meaning "I...] the unpremeditated, attentive facing up to, and resisting of, reality - whatever it may be (ARENDT, 1973, p. viii). In this context, the enforcement of past normative standards on unprecedented events, veiling their significance along with their concreteness, plays an ideological role whose purpose is to prevent questioning, critical reflection and the dispelling of prejudices, the first and foremost task of politics (ARENDT, 2005). Ideology claims to have all past, present, and future events within the grasp of its explanatory power, becoming independent of experience and emancipated from reality. Ideology becomes a kind of sixth sense that supposedly makes its followers more apt to penetrate the underlying nature of reality, a reality that, for ideological reckoning, hides under the veil of appearances. This opens the way to a conspiracy prone maniacal mind, intent on discovering hidden meanings and purposes in every single event and willing to ignore the facts that do not fit its worldview, whatever it might be, and eventually to ignore facts altogether. Such a mind is filled with all kinds of theories particularly fit to be used for indoctrination purposes through propaganda or some kind of training in educational institutions 
put in place with that aim (ARENDT, 1973).

Furthermore, ideology operates through a naturalization of prejudices, which then become the unthought-of, axiomatic "idea" - normative standard - automatically applied to the understanding of everything that happens, both old and new, resulting in a logically consistent worldview (ARENDT, 1973). This inability to think, manifested in the absolute inattentiveness to the claim made by events for the simple fact of their existence, is related to Arendt's "banality of evil" (2006b; 2003), the acritical, automatic, naturalized reproduction of behavior without consideration of facts, conditions and their unprecedentedness. The abandonment of individuals and groups to behavior alienated from reality is one of the most disturbing aspects of the current ecological crisis, considering its potentially ruinous consequences - for us, human beings, as well as for the Earth, which we share with other species.

The "ecological crisis" is the current name for that "[...] state of crisis underlying the many crises in almost all fields of human endeavor [...]" (ARENDT, 2018, p. 328) indicative of the need to address the prejudices or normative presuppositions guiding the current human way of living together and of understanding all aspects of life. Humans are question-asking beings: existence is given to humans as factual crisis (ARENDT, 2005; NEGRI, 1999). Insofar as asking questions is directly related to the dispelling of prejudices and to the human ability of starting anew - of being free -, the rethinking of the normative presuppositions structuring our everyday behavior is a re-connecting to our critical reality and, ultimately, a reconsideration of the fact of human existence. In other words, a re-connecting to and a reconsideration of the ontologically rooted fact of natality, the condition of possibility of freedom, in a movement that, paraphrasing Agamben (1998), sends politics back into its ontological origin.

The ecological crisis is a two-pronged ontological crisis: environmental, regarding our relationship with nature and the basic conditions of life on Earth shown in facts as biodiversity loss, climate change, global warming, ecosystemic destruction, etc.; sociopolitical, regarding our way of living together and our condition of beings-of-the-world, beings for whom some sort of institutional, legal shared order is their place of dwelling - shown in facts as the globalization and its effects on communities and individuals, poverty, the refugee and migrant crisis, the collapse of social and political institutions and the ensuing crisis of politics. At the core of this crisis is the "future man", described by Arendt as being "[...] possessed by a rebellion against human existence as it has been given [...]", seeking to exchange it "[...] for something he has made himself" (ARENDT, 1959, p. 2-3). For all purposes, the future human being is already there, equipped with the ability "[...] to destroy all organic life on earth" (ARENDT, 1959, p. 3). The systematic refusal of existence's givenness - the basic conditional, factual character of existence and the belief in the ability of human self-production - the drive to reference back everything to the Self either reducing to it or destroying every remnant of otherness - are decisive constituting elements for the transformation of the ecological crisis into an ontological crisis, a crisis where everything is at stake.

The notion of "givenness" (Gegebenheit) is the core principle of phenomenology, with origins in Husserl (2001). It is indicative of the fact that every experience contains a dative element, in the sense that every experience is characterized by the giving of something to someone, in a correlation whose terms appear at the same time and together, conditioning each other but distinct from each other. The refusal of givenness corresponds, in Arendt's terms, to the human rebellion against everything given, even what humans have not created: the fact of life itself. This refusal amounts to the human being's attempt to be sovereign over everything that is.

Obviously, Arendt is not ignoring but rather emphasizing the difference between arguing for the relevance of givenness in human experience and arguing for the blind acceptance of what is specifically given. One must acknowledge and care for one's given, factual life, even if one chooses to put an end to it. However, one is not duty bound neither to accept the circumstances determined 
by the way one's community of birth is organized nor one's pre-established place in it, whether physical or otherwise. As Herbert Marcuse would say, a certain amount of alienation - something given, other - is an integral part of human finite, conditioned lived experience; the problem lies in "surplus alienation", in "....] alienation exacted by the existing society in the interest of maintaining and enlarging the status quo [...]" (MARCUSE, 2001, p. 197), i.e. in being over-determined by what is given. Consequently, givenness merely refers to the human existence's dependence on a set of conditions that are factual, given in and by themselves to newcomers as if they were natural, no matter how contingent and even unnatural they may be. The success of the human being's efforts to be autonomous notwithstanding, there will always remain a trace of givenness in human existence, humans will always live within some kind of "nature", within something given conditioning them, even if it is human-made or self-made. In fact, for Arendt, being conditioned is the defining trait of human autonomy:

Man is not conditioned by (magical, natural, social, emotional) forces. As a living being, he is conditioned by the earth (the thing of all things), and as a human being man is conditioned by the things he himself produces. As a human being, man conditions himself. That is his 'autonomy'. He gives himself primarily not laws, but conditions in things. All laws are secondary to these conditions. Without such conditions, human life cannot exist. (ARENDT, 2003, p. 310-311)

The environmental and political dangers of remaining unaware of givenness are visible in the ecological crisis and its consequences, mainly due to the naturalization of human relations and its related alienation. ${ }^{5}$ By overlooking the distinction between being conditioned and being over-determined by a given set of conditions or norms -, the human being is set on the path to ecological destruction.

\section{Globalization, Capitalist Ethos and Technoscience - The Origins of the Ecological Crisis}

What are, then, the origins - i.e. the contingent experiential grounds - of this crisis, ruling the current factually given and somewhat naturalized human life?

"Origins" are not the same as causes. Whenever she spoke of origins, Arendt was neither isolating some law - historical or natural or yet a mixture of both - determining the motion of human development nor defining some sort of human essence or nature unfolding in time. She was carrying out an essay in understanding based on a set of contingent elements - facts, events, decisions, and experiences - that crystallized in a critical situation.

The origins of the ecological crisis lie in the Modern Age, whose essential experiences were decisive for the constitution of the modern world and its perplexities. In her treatment of alienation and the Modern Age in The Human Condition, Arendt analyses three experiences - the discovery of America and the exploration of the Earth, the Reformation and the rise of the money economy, the invention of the telescope and the emergence of Modern science (ARENDT, 1959, seç. 35-40) - that constitute an essential experiential nexus regulating our current way of life as a prejudgment. The examination of that presupposed normative nexus and its unexpected consequences i.e. "thinking what we are doing" - is crucial to deal with the current ecological crisis and to understand and justify the appearance of children and teenagers in the public space. Globalization, capitalist ethos and technoscience are the three experiential elements, originating in the Modern Age, which crystallized in the modern world and rule its organization and web of relations.

\section{Globalization}

Arendt describes globalization as the process of increasing abolition of distance - space - and its replacement by speed - motion and change,

\footnotetext{
5 Arendt makes this point particularly clear in her discussion of the life process of society and its dependence on behavioural automatism and mass indifference in (ARENDT, 1959)
} 
time (ARENDT, 1959, seç. 35). The process started with the discovery of the New World and the exploration of the Earth and came fully into existence in our time. The dissemination of cultural and economic exchange, mostly through wars for the domination of people and resources, resulted in the increase of political and socioeconomic activities to a global scale. The counterpart of this expansion was the shrinking of the Earth's globe, translated into the creation of increasingly complex trade systems and networks whose flows progressively encompassed human activities.

The physiognomy of human communities was thus transformed and individuals with them, who became inhabitants of the world and not just of their region. Globalization, with its universalized market and processes of production, fundamentally changed the relation between individual and community. In the process, the different territories of the Earth were conquered by and reduced to the abstract measuring standards and functions of the valuational, trading, calculating capacity of the human mind. The latter became socially and politically effective in the coupled phenomena of the political emancipation of the bourgeoisie, "[...] when the bourgeoisie [...] established itself as the ruling class [...]" -, and imperialist expansion, - "[...] when the nation-state proved unfit to be the framework for further growth of capitalist economy [...]" (ARENDT, 1973, p. 123). In fact, one of the most relevant outcomes of the expansion of the human mind's abstract valuational capacity, along with its economic and technological devices of political domination, colonization and imperialism, was the abolition of differences and deterritorialization - Arendt's expropriation of property and alienation of both the world and the Earth (ARENDT, 1959) -, with the ensuing erosion of the pre-existing institutional apparatuses - "[...] the downfall of politics [...]" (ARENDT, 2005, p. 94). According to Bruno Latour, "[...] there is no planet suited for globalization [...]" (2018, seç. 2. parag. 16) and we are thus experiencing a generalized migratory crisis characterized by deprivation of land. In a sense, economic migrants, refugees, and newcomers became the epitome of the globalized human being. Idiosyncrasies, differences, particularities, ways of life, in short, distinct stable territories both at home and abroad underwent expropriation, and their significance was reduced to the only common denominator abstract enough to operate in the speculative financial market of capitalist economy and its ever-increasing speed: money.

\section{Capitalist Ethos}

Arendt's analysis of world alienation partly resumes Max Weber's description of the relation between the Reformation, its innerworldly asceticism and the ensuing social relations, which gave rise to the capitalist mode of production, and is centered on her characterization of the exclusive care of the Self as one of the traits of Modern Age (ARENDT, 1959, seç. 35).

In The Protestant Ethic and the Spirit of Capitalism, Weber (2005) established a connection between the Calvinist doctrine of predestination, the radical isolation of individuals it entailed, and the establishment of the capitalist ethos of contemporary society. According to that doctrine, God predestined a few human beings to eternal life and the remainder to eternal damnation. Consequently, individual existence is radically isolated from every worldly relationship and thrown back upon itself instead of thrown into the world. Individuals show their faith in God and justify their election through everyday labour and its products, producing and reproducing self-assurance in salvation by doing God's work. Secular life, the world, worldly relations and the social good have an impersonal and utilitarian character; they are the means used to glorify God's divine purpose in the rational organization of society through labour and, therefore, to reaffirm the elected faith in eternal, otherworldly life (WEBER, 2005, p. 56-65). From a worldly standpoint, this means that wealth and its accumulation are not reproachable in themselves, but only as sources of temptation. In fact, the production of goods and the accumulation of money - the overarching, abstract symbol of their value as means of glorification - is encouraged 
(WEBER, 2005, p. 103-104) Produced goods and accumulated wealth are "standing-reserve" (HEIDEGGER, 1982, p. 17); they are gathered and arranged as potentialities of self-assurance in view of ensuring the furtherance, on the one side, of the labour force - whose immediate product is one's own survival and reproduction - and, on the other, the accumulation of wealth and capital - the ultimate measure of one's own faith in eternal, otherworldly life. For this mode of relation, labour and the accumulation of wealth are morally praised as social manifestations of interest in one's otherworldly salvation.

The Modern Age was the age of secularization, but this did not entail the transformation of the Self's interest in eternal life into interest for the world, its materiality and the production of stable, enduring things (ARENDT, 1959, seç. 35). The Modern Age was the moment of human emancipation from transcendent standards, as well as from the cosmos and the socially fixed hierarchy they supported. This emancipation granted a new dignity to the realm of immanence. However, it was also the time of reasserting pre-modern transcendent standards not in themselves, but as laws of nature or laws of history driving the course of human relations. The Modern Age was marked by this tension, which was eventually sublated and turned into an ideologically driven view of the progress of humankind (Arendt, 1959c; Hardt \& Negri, 2000). The process of ensuring individual otherworldly eternal life through labour lost its transcendent reference - God - and fell back upon itself, becoming the immanent life process of society, with its own economy of relations and productivity. This process' striving for eternal survival requires all things to be produced, consumed or stand in reserve as goods and eventually as capital in order to be put to its service as needed - individuals and their self-interests included as the so-called 'human capital" of neoliberalism (HARVEY, 2005).

The self-centered life process of society consumes everything stable in its way, reducing to its own needs all things that may transcend its purpose of survival. This includes property - one's own territory or place of occurrence in the world - along with its last remnant in our time, privacy - one's own individual, unique, distinct character. In the deterritorialized modern world, privacy is the last refuge of one's own dokei moi (ARENDT, 2005), the unique way the world appears to an individual, comprised of two interconnected, inseparable and almost indistinguishable parts:

1) One's body, whose care and behavior are already almost fully administered in the name of the needs of the life process of society and,

2) One's inner dispositions and mind, whose idiosyncratic desires, interests, emotions, and, most of all, thinking and judging ability are subjected to the unrelenting onslaught of the depersonalizing, normalizing, taming force of the socialized life process, its needs, motion and ideological unfolding, set on turning individuals into functions of society's survival.

Therefore, the Modern Age's care and worry for the Self became, in our world, not care and worry for one's own self, but rather for the life process of society; the latter, in its turn, became a kind of global, bureaucratic Über Selbst (ARENDT, 1994, p. 182). If the expression "Über Selbst" sounds totalitarian that is because we live in a post-totalitarian society, in itself not totalitarian, but where totalitarian elements are present and fully at play. In this society, individuals are desubjectified, expropriated of their unique selves along with their needs and desires, becoming functions of the only subject that matters, the social process of production and consumption. The process of desubjectification, the production of the selflessness of the masses and the ability of the mass individual to play whatever role the bureaucratic machine of the life process of society assigns to him is one of the increasingly decisive elements of our current way of living. For Arendt, "the peculiar selflessness of the mass man appeared [...] as a yearning for anonymity, for being just a number and functioning only as a cog [...]" (ARENDT, 1973, p. 329). This selflessness derives from the feeling of alienation, which makes individuals yearn for becoming a function in the process instead of being thrown back into 
a condition of having no place in the world, of being isolated and uprooted ${ }^{6}$.

In our consumer's society, this link between isolation, uprootedness and selflessness was translated into an increasingly faster process of production, consumption, accumulation and circulation of both goods and capital that not only is alienated from the limits of the world wherein it takes place, but also dependent upon that alienation for its own survival. ${ }^{7}$ The ultimate end of the current global household administration is the expropriation - deterritorialization -, desubjectification and subsequent dereliction of one's individual, unique existence into a depersonalized, alienated expansion of collective self-assurance. This expansion is a kind of allencompassing, species-driven process of confirmation bias, operating through individuals transformed into willing labouring functions put at the service of the furtherance of life's socialized process of production, reproduction, and consumption. The difficulty in garnering public support for effective action regarding the ecological crisis and the alienation of the masses from its effects, regardless of the impacts on their lives or the lives of their children, is a daily manifestation of the efficiency of this process in turning individuals into jobholders in a society that

[...] demands of its members a sheer automatic functioning, as though individual life had actually been submerged in the over-all life process of the species and the only active decision still required of the individual were to let go, so to speak, to abandon his individuality, the still individually sensed pain and trouble of living. and acquiesce in a dazed, 'tranquilized', functional type of behaviour. (ARENDT, 1959, p. 322)

The recurring social demand for an escalation in productivity is the expression of the automatic character of this impersonal expansionist process. It is also an expression of our own everincreasing individual addiction to it for providing a remnant of validation to our otherwise seemingly absurd existence as functions of its production, reproduction, and consumption in the role of labourers, jobholders, and consumers.

\section{Technoscience}

The third element of this Arendtian triad is the invention of the telescope by Galileo and the discovery of the Archimedean point, i.e. the rise of modern science or technoscience.

Broadly speaking, technoscience is characterized by the crucial role the means/ ends or instrumental relation plays in every epistemic endeavor. Technoscience is based on the human technology's ability to produce - in the Latin sense of pro-ducere, to bring forth truth or, at least, its modern substitute, certainty. This is achieved by using instruments that force the internal processes of a universal Being into appearance, a Being that, left to itself, seems to elude and deceive the human sensory apparatus. Such an understanding of Being is in stark contrast with pre-Modern conceptions of nature or physis, characterized by givenness and appearing in and by itself (ARENDT, 1959, seç. 20 and 38). In the process of producing truth/certainty, human

\footnotetext{
6 The alliance between the Evangelical churches' conservative social agenda and the neoliberal political right is a good example of this at work. This alliance shows the effectiveness of the former in indoctrinating its depoliticized followers in some of the beliefs it shares with the latter: extreme individual isolation; the redeeming power of labour; wealth as a manifestation of divine election; and poverty as a manifestation of damnation. A similar process of indoctrination is taking place in the Global South, particularly in poor areas where the state is almost or even totally absent, through the Pentecostal churches, a process that has accompanied the rise of right-wing populism and the implementation of neoliberal economic policies. These churches share some of the generic traits described in Weber's analyses, although with some differences. The differences are more in tune with the neoliberal capitalism's appeals to emotional states and impulses, particularly those involved in consumption (KIRBY, 2019). Even though the notion that this emotionality is opposed to the rational logic of capitalism may be correct at first sight, it may also be its next step, i.e. its internalization at a deeper, emotional, almost organic level, ideologically framing its subjects' entire view of the world. The end of ideology is not necessarily its demise; it may be the moment it is fully realized into its purpose of domination, in this case into the Über Selbst of the modern world, the naturalized consumer society described by Arendt in The Human Condition, along with its needs, interests, emotional states, and desires. This extreme internalization of prejudices, along with the sense of functional, bureaucratic belongingness they carry with them, is an integral part of the process of naturalizing the world and human living together, i.e. politics. From this point of view, the alliance between neoliberalism and the Pentecostal churches makes perfect sense. They share a common interest in the naturalization of social relations: on the Pentecostal churches' side, the conservative moral agenda of naturalizing social behaviour and custom - the patriarchal family, relations between sexes, gender issues, and so on; on the neoliberals side, the goal of naturalizing the political and economic status quo, a significant part of which is dependent on the preservation of the bourgeois patriarchal paradigm of society by appealing to people's deepest prejudices. The result is a mutually positive interaction whose outcome is, for both, a complete ideological transformation of society in accordance with their worldview.

Besides Arendt, David Harvey and Joel Kovel also make excellent cases in favour of this view. See Harvey (2005) and Kovel (2007).
} 
beings impose the conditions of their minds and expertise to sense data by way of the experiment, thus controlling and forcing nature to conform to human purposes and conditions.

Dependence on the ability to produce effects to validate knowledge is one of the key elements of Modern science as technoscience. In the context of science as technoscience, to know is to be able to exercise dominion over causes and control them experimentally, producing and reproducing their immediate effects at will. The measure of success of any epistemic undertaking is, from this viewpoint, applicability.

In its earlier stages, the end and ultimate limit of modern science and its ability to produce truth was to put nature at the service of the improvement of the human condition, identified with the progress of humankind (BACON, 2000). The historically contingent character of the human condition and the measure of its improvement's dependence on factuality made it difficult to reach abstract grounds, automatically applicable to every time and place. To deal with this obstacle, the particularities and factuality of the human condition were sublated into the production process itself and its criterion of success - the bringing forth of effects -, which then became the self-referential universal ground and subject of progress. In consequence, the measure of improvement was no longer dependent on factual human beings living in factual conditions, limited by definition; instead, it became dependent on the increase of the production of effects, on the ability to produce change for the sake of change at an ever-increasing speed. Oddly enough, the sovereignty of humankind over nature and the imposition of the former's purposes upon the latter was itself naturalized as an encompassing process of production, seemingly appearing in and by itself and on its own grounds at the cost of the functionalization of human beings ${ }^{8}$, reducing the homo faber to the animal laborans (ARENDT, 1959, seç. 20).

In the context of the pre-eminence of the technological viewpoint, which expropriates nature of its givenness in order to take possession of it as an always abundant resource at hand, re-producible at will under experimental conditions, the attention given to nature's limitations, even those imposed upon the production process by the conditions of life on Earth, is not a priority. For Arendt, "[...] even at the risk of endangering the natural life process, we expose the earth to the universal, cosmic forces alien to nature's household [...]" (1959, seç. 262) to a "[...] truly 'universal' science [that is, without stable referents and therefore relative to its own ability to re-produce itself] [...] which imports cosmic processes [that is, deterritorialized, without limits] into nature even at the obvious risk of destroying her and, with her, man's mastership over her" (ARENDT, 1959, p. 268)

The simultaneous alienation of the world and the Earth as grounds for human life was an unexpected consequence of these experiences and their subsequent development. It explains our time's recurring and somewhat paradoxical insistence on increased productivity in every area of activity of a society that was never as rich and yet never had so many poor people. What started, in the earlier stages of technoscience, as the purpose of disposing nature as a material means for human ends resulted, when applied to the human being through the deterritorialized, abstract notion of the progress of humankind, in the transformation of individuals into means of production, reproduction and consumption of the goods necessary to the subsistence of the anonymous social subject governed by an autonomous, automatic and naturalized law of development. The subjectification of the process of production and consumption was accompanied by the desubjectification of individuals in the process of socialization. Under the bureaucratic rule of this socialized being. finding differentiated meaning for each one's own existence became more and more difficult while, at the same time, delivering oneself to the absurd of functionalization became increasingly natural.

On the side of nature, impacts came from the unlimited expropriation of its limited resources and their appropriation as matter to be used in the vital process of society, marked by a global

8 See Agamben's anthropological machine (AGAMBEN, 2012). 
and deterritorialized capitalist mode of production perfectly attuned to the universal relativism of technological relationality. The operation of such a mode of production is characterized by a systematic testing of limitations - natural, political, institutional - and their stability not with the aim of respecting or reshaping them, but with the purpose of sublating or destroying them. Its aim is to perpetuate the process of expropriation and appropriation by finding new locations for expropriation, value production and wealth accumulation, regardless of the imbalances caused and their consequences. The process of accumulation of wealth characteristic of the capitalist mode of relation is incapable, by definition, of stopping before any given limits since its survival is dependent on the drive for continuous expansion. In this framework, there seems to be no way of reconciling it with the ecological crisis. On the contrary, the production of such a crisis - in both its environmental and socio-political dimensions - seems to be constitutive of its essence?

\section{Ecological Crisis and Youth in Politics: an Arendtian Justification}

In reaction to this state of affairs, children and teenagers from every corner gathered in several movements - the Climate Strike movement and, to some extent, Extinction Rebellion, for example, among others - questioning its normative grounds and demanding that the world's political leadership take responsibility and commit to concerted, meaningful action to stem the process of ecological depletion. These movements were contemporary to the appeals of the United Nations' Secretary-General, António Guterres about the need to work on measures to deal with the current crisis efficiently and sustainably. One and the other ran into a wall of special interests, inertia and lack of political will - see the disappointing results of COP 25 (NATIONS, 2019b) -, accompanied by mass indifference, faithfully reproducing the behavior described in the previous sections.

The participation of children in politics is a particularly relevant issue for Arendt, whose position on the subject became known during the process of school desegregation in the United States of America, particularly regarding the events in Little Rock. In Arendt's view, for adults to put children and teenagers at the center of political debates and disputes that should be the domain of adult intervention is problematic. Adults are evading responsibility and their duty to shelter and guide children and teenagers into a world that is utterly alien to newcomers (ARENDT, 2003). Ultimately, as shown below, they are depriving children and teenagers of their right to be children and teenagers. Although her position is arguably sustainable in its essence, Arendt provides us with elements allowing us to conceive of circumstances where children and teenagers should make their appearance in the public space, the current state of the ecological crisis included.

One of the elements mitigating Arendt's misgivings regarding the participation of children in political disputes comes from her reply to the criticism she received from Ralph Ellison. When asked about Arendt's views on the events in Little Rock, Ellison said she misunderstood the situation by not considering "the ideal of sacrifice" (WARREN, 2014, p. 343-344) involved in it. For Ellison, this ideal was a kind of rite of initiation for young people - in the specific case, young African-Americans - consisting in a direct confrontation of the terrors of social life they are exposed to and demanding they dominate their fear and internal tension, if needed with personal sacrifice. It was the

[...] basic, implicit heroism of people who must
live within a society without recognition, real
status, but who are involved in the ideals of
that society and who are trying to make their
way, trying to determine their true position
and their rightful position within it. (WARREN,
2014, p. 342-343)

In short, the heroism of people who cannot "[...] afford to take their own place in society for granted. They might not be able to spell it out philosophically but they act it out."(WARREN, 2014, p. 343) In her reply, Arendt acknowledged her

9 For an exploration of the ecological implications of capital's barrier/boundary complex see Kovel (2007, cap. 3). 
misunderstanding of the issue by saying that her reflections should have started from the "ideal of sacrifice" (ARENDT, 1965), which is not surprising, given her own experience with antisemitism and her view on the appropriate reaction to it: "If one is attacked as a Jew, one must defend oneself as a Jew. Not as a German, not as a world citizen, not as an upholder of the Rights of Man, or whatever" (ARENDT, 1994, p. 12). For this principle to be valid for the movements of children and teenagers who are concerned with the ecological crisis, an answer must be given to the question: how is one attacked as a child?

In Crisis in Education, Arendt says "...] the essence of education is natality, the fact that human beings are born into the world" (2006a, p. 171) In this essay, the author argues for "conservatism in education", since the function of education is to try to preserve facts impartially and, in doing so, to preserve the potential plurality of interpretations of facts and events that is proper to the public sphere and to politics. Similarly to givenness, it is not the case that Arendt is defending conservative politics in educational issues; instead, she is arguing for the effort to preserve facts in the most impartial way imaginable so that the possibility of the new and of political freedom are also preserved and, with them, the ontologically rooted fact of natality embodied by each new generation. Obviously, Arendt was not naive to the point of thinking that a neutral conveyance of facts is possible or even desirable. However, this does not mean that a critical effort of impartiality should not be present in the teaching process as a kind of epochê to which every teacher, at whatever level, is duty bound. This epoche does not guarantee the total absence of presuppositions in the process since, for Arendt, it is humanly impossible to live without presuppositions (ARENDT, 2005), but it may provide a methodological framework for accessing facts and conveying them as impartially as humanly possible. The opposite of this attitude, the intentionally partial transmission of facts in education, corresponds to an over-determination of the possibility of the new by the prejudices of the past, to an ideological contamination that tries to expropriate and may even prevent the future exercise of political freedom by the individuals in formative process. So, in fact, Arendt's defense of conservatism in education actually corresponds to a refusal of the conservative attitude in politics, which "I...] accepts the world as it is, striving only to preserve the status quo [...]", leading "....] to destruction, because the world [...] is irrevocably delivered up to the ruin of time unless human beings are determined to intervene, to alter, to create what is new [..." (ARENDT, 2006a, p. 189), i.e. to set it right.

Ecologically speaking, the cost to be paid by the conservation of the current political, social and economic status quo is the expropriation of the life potential of future generations, of the environmental and socio-political basic conditions making their existence humanly possible and their capacity to begin anew sustainable. In a world of disinformation, pseudoscience, unlimited belief in technology and so-called "alternative facts", sustained by forms of propaganda and organized lying of unprecedented reach and capacities, the duty of education toward impartiality and facts is essential. It is the last defence against the alienation and even possible annihilation of the ontologically rooted fact of natality and the potential for freedom in each generation of newcomers.

As stated above, the subsumption of the new by the old, the former's reduction to the latter in unprecedented situations, corresponds to an illegitimate enforcement of the past's sovereignty over the present and the future. It reduces the factual present and the unforeseeable future to a kind of fictitious, acritical perpetually changing present that, however, is lacking in history. Delivered to itself and alienated from facts and actual conditions of existence, this process can only eternalize itself as a process of destruction - consumption - that, in virtue of the newlyacquired human ability of acting into nature, may lead to the destruction - consumption - of the basic conditions of life on Earth themselves (as it seems already to be the case).

As in Ellison's sacrifice, children and teenagers living in the current context of ecological crisis cannot afford to take their place in society for 
granted. Even worse, they cannot afford to take the fact of their existence and subsequently their future for granted. Children and teenagers - the newcomers - of today did not choose to enter the public realm; they were violently thrown into it when the simple ontological fact of their existence became politically relevant because it was endangered by the status quo. They are being directly attacked as children - and not simply as living beings - because they are being attacked in their capacity of generating something new, of being a beginning, of acting. One is attacked as a child if one is attacked in one's capacity to begin anew, in the ontologically rooted fact of natality that is the given precondition of political freedom, a capacity shared by all human beings, adults and children alike, as free entities. In this sense, everybody is under attack; children seem only to be more aware of it than most. The sacrifice demanded from children and teenagers today is that they face the speechless wonder and terror brought about by the awareness of their pure and simple existence as newcomers being endangered by a social mode of relation that is not only hostile toward them, but also seems invested in destroying their future and its unforeseen possibilities. This is the awareness of a skandalon (ARENDT, 2003), of an obstacle - like the ecological crisis - that cannot be removed and is beyond our power to repair, thus remaining an obstacle for future generations as well. The fact that we are unable to repair it means only that we are unable to restore the balance and conditions before its occurrence; it is not and needs not to be an expression of doom, hopelessness, or defeatism. As occurs with skandala, it would have been better if it had not come to be. Nevertheless, since the ecological crisis did come to be because of our mode of social relation and our ability of acting into nature -, it has become our unprecedented, factual living condition.

Insistence on carrying on as before without stopping to pay attention to facts - above all, to the endangered fact of our existence - and think about what we are doing is to surrender ourselves to the processes of desubjectification, to the ensuing absolute alienation and to the banality of evil. By calling attention to the issue, children and teenagers are showing their refusal to be desubjectified and alienated - at least, of being the passive material for surplus alienation. They are demanding of adults that they face the same speechless wonder and, more importantly, horror they are experiencing in virtue of existing in a time of ecological crisis, when seemingly everything became possible for human beings, even the destruction of life's given basic conditions. Such wonder and horror before everything there is and before what the world may become constitute, for Arendt, the philosophical experience of our time, an experience that may open the way to a new political philosophy (ARENDT, 1994) and therefore to new ways of living together. By acting out in a very peculiar way, children are philosophizing, even if they are not able of spelling it out, to borrow Ellison's words. With their climate strikes, children and teenagers are trying to make adults pay attention to facts, are making them stop to question and criticize their scandalous way of being together. In striking, they are being active while apparently doing nothing, as in Cato's sentence with which Arendt closes The Human Condition (ARENDT, 1959, p. 325). They are opening space for the thinking activity, for its prejudice-destroying capacity, thus preparing the way for judgment, action, and the appearance of the new into conditions that are fit to shelter them, to be their home. This legitimates their presence in the space of public debate, albeit in a very peculiar way and in a very particular context, the current context of the ecological crisis, a context where the meaningfulness of their future and even the physical fact of their existence is at stake. Their existence is threatened by the abandonment of the masses to the automatic and self-referential destructive process of production and consumption. This threat is enhanced by the alliance of political leaders with the masses to preserve the status quo and the capitalist ethos that sustains it, even if the world and the Earth supporting it perish on the way. 
Youth Movements and Ecological Crisis:

\section{A Case for Civil Disobedience}

In the current context of the ecological crisis, how can children and teenagers meaningfully convey their experience of speechless wonder and horror, along with its political implications, without risking ideological co-optation? The straightforward answer is non-participation and its most meaningful political consequence in contemporary societies: civil disobedience. The process of non-participation has two related but independent dimensions: a moral, pre-political dimension; and a properly political one.

The moral dimension pertains to one's constitution as the subject of one's own life, one's subjectification in a context ruled by an overall process of desubjectification, as is the case with contemporary societies. This process is guided by the disposition to dialogue with oneself, to be at home with oneself in the twoin-one (ARENDT, 1978a). The sentences chosen by Arendt to illustrate the process of constitution and preservation of one's dignity as a subject are Socratic in origin: "[...] it is better to suffer wrong than to do wrong [...]" and "[...] it is better for me to be at odds with the whole world than, being one, to be at odds with myself [...]" (ARENDT, 2003, p. 90) That same dignity, entirely based on propositions valid only for the subject experiencing them, is instituted as the measure of the distinction between good and evildoing and as the self-imposed prepolitical condition for those willing to be the true protagonists of their actions, regardless of the normative determinations of their community.

The political dimension regards nonparticipation in public life as a form of resistance, more specifically as civil disobedience. This dimension is indirectly related to the moral one, which works as a kind of pre-political necessary, although not sufficient, condition for political non-participation. The former is not the sufficient condition or cause of non-participation because it does not have the nature of an imperative, it does not determine action or influences the assessment of its goodness or evilness by the world; it is a negativity indirectly experienced by the subject as the moral boundary of its (political) action. Phenomenologically speaking, the moral, subjective boundary for action is grasped, in action, en parergo or in passing as the exemplary other who bears witness to the subject's intervention in the world and with whom the subject must live, i.e. with whom it must be at home.

Non-participation is the public appearance of the subject's withdrawal of support to the actions of its community, a refusal to be implicated in the community's actions that is usually interpreted as irresponsible. This refusal may have different reasons, from disagreement regarding specific laws and policies to the subject's acknowledgment of its impotence to change the status quo. The word "responsibility" stems from the Latin "sponsor", the one answering for another or taking another's place before the demands of the world and its institutions. Regarding children and teenagers, this responsibility is usually taken on by adults, who commit themselves to welcome and shelter them as newcomers to a world which is there before the children's arrival and will one day become their responsibility to preserve as a space where future generations are welcome and be at home. The price to pay by newcomers for the welcome, shelter and protection of the community is the implicit recognition of their duty of obedience to its laws, in other words, their tacit consent. On the basis of this tacit consent is an agreement binding each individual with its fellow citizens, a mutual compromise that creates a clearly defined, stable and lasting common reference - a world - in the context of overall change characteristic of life, and more so of human life. For Arendt, this generic consent is not a theoretical fiction - as in Hobbes or Locke, for example - but a fact of the human condition utterly different from the explicit consent concerning specific laws or policies (ARENDT, 1972). In short, human existence is factual being-ofthe-world, given to each individual as immediately public and political.

In the current stage of the ecological crisis, a stage of world and earth alienation accompanied by political apathy, the mutuality grounding tacit consent is at stake in virtue of the inability of the 
pre-existing community to fulfil its promise of welcoming, sheltering and protecting implicitly made to every newcomer. The significance of this inability to fulfil promises is, for children and teenagers, an unprecedented uncertainty not limited to the social and political fields, but also striking them directly in the fact of their existence and in the related ontologically rooted fact of natality. The fact their mere existence entered the political stage and became politically relevant was and is beyond their power. However, their acknowledgment of their own impotence in that regard has a decisive political meaning: it is the recognition, in their actual experience of the state of the world, of their own potential mortality, of finitude as their own possibility. Consequently, it is a restoration of their existence as power by way of the experience of its possible privation (AGAMBEN, 2000), the basis of a possible rebirth or reassertion of the ontologically rooted fact of natality and the ability of beginning anew, as timid and fragile as it may be. The consequences of this reassertion for the pre-existing community are the following:

1. If the community children and teenagers are thrown into in virtue of being born has not yet ceased to be as a consequence of its infringement of the mutuality necessarily presupposed in tacit consent (infringement of the promise to be responsible for newcomers and their lives),

2. If the validity of tacit consent presupposes and is dependent, as in every consent, on it being freely and voluntarily given,

3. Then dissension - the power and possibility of establishing boundaries for the possibilities of action of the community, that is, of establishing the limits of the community's own impotence has to be a lawful possibility, it has to be a right (ARENDT, 1972).

In the case of the movements of children and teenagers, politically and ontologically at stake in virtue of their mere existence, the right to dissent ensues from the recognition of their inability to change a past they did not create and that has seemingly become an unsurmountable obstacle - a skandalon. Non-participation of children and teenagers becomes the public manifestation of this recognition, the manifestation of a last remnant of power, the power of not acting, of not consenting, of not supporting a status quo set on expropriating and, if needed, actualizing their own individual potential mortality in the name of its selfish preservation. From the point of view of the status quo, non-participation is a sign of irresponsibility and, as shown above, a disturbance of the otherwise smooth functioning of the bureaucratic social machinery and its cogs. From the point of view of the subject - in this case, children and teenagers -, non-participation is the only responsible attitude in a situation where its own existence, in its ontological basis, is at stake. For children and teenagers, regular participation is comprised of non-intervention in political disputes and attending school in preparation for becoming full acting citizens of their respective communities..$^{10}$ By refusing to go to school, i.e. by striking and not fulfilling their socially prescribed role, children are exercising their right to dissent precisely as children. In doing so, their attitude of non-participation becomes non-violent civil disobedience, it reifies the ecological crisis as a skandalon, turns it into a worldly thing, an obstacle appearing for all to see and a problem - a task thrown before everyone - for all to address. By reifying, with their refusal to participate, something that should never have been brought into existence, the non-action of children and teenagers becomes a form of resistance - both literally and figuratively - in the context of the overwhelming, self-referential, automatic bureaucratic life process of society and its consumptive, destructive productivity.

\section{Conclusion}

Thinking the ecological crisis and pursuing its origins - capitalism, technoscience, and

\footnotetext{
10 Obviously, this is not the case everywhere since there are many issues - child labour, poverty and extreme poverty, war - preventing children and teenagers from enacting their rights. Even so, this fact cannot be legitimately used as a reason to deprecate the efforts of children and teenagers whose living conditions are infinitely better that those affected by extreme poverty, war and exploitation of any kind, whose voices are thus violently silenced. After all, it may well be that the latter's predicaments are a product of the mode of social relation that is at the origin of the ecological crisis.
} 
globalization - showed that this is not a temporary crisis of our way of living, able to be answered within the current normative framework or solved once and for all. It seems rather the sign of a collapsing worldview. Given the power of human action and its consequences - both actual and potential -, it became our inescapable existential condition, an irremovable skandalon, even if it is masked by the efforts of self-preservation of the status quo through ideological thinking and acting, efforts that may well send life on Earth as we know it on the way to its destruction. Facing the possibility of an absence of or, at least, an unprecedently unpredictable and difficult future, children and teenagers addressed the scandalous situation of being existentially put at risk by the community that was supposed to welcome and protect them through civil disobedience, precociously becoming political subjects in their own right.

In her 1957's essay on the events in Little Rock, Arendt asked, "Have we now come to the point where it is children who are being asked to change or improve the world?" (ARENDT, 2003, p. 204)

I would not go as far as that. The issue is not to turn children and teenagers into professional revolutionaries or into political instruments of adults through ideological training, thus restricting their potentiality for freedom and making them the desubjectified implements of their own possible demise. The truth is that conditions were created so that their existence became politically relevant and the masses of adults showed to be either indifferent or willing agents in the deepening of the ecological crisis and the existential risk associated with it. Therefore, children and teenagers had no other option but to passively resist by striking and occupying the places that are their own, exercising their right of nonparticipation in a politically consequent, although somewhat indirect, way. In dissenting through civil disobedience, children and teenagers seem to agree with Arendt: like every newcomer, they do not wish to change the world; they only want to restore it so that it may become their home.

The consequences of their non-participation are unpredictable. It is probable that their efforts are co-opted and put at the service of the continuity of the social mode of production and consumption at the origin of the ecological crisis, even if in a different guise. This risk notwithstanding, it may so happen that their stance becomes the unintentional catalyst of a concrete process of revolutionizing our way of living together, an exemplary attitude exerting its influence on others en parergo. This is not the same as finding a definite, final solution for the event of the ecological crisis since it is a skandalon and it is here to stay. However, maybe it will be just enough to make us face, as a community, the speechless wonder and horror of everything there is and lead us to discuss and define urgent measures to put a stop to or at least slow down the course of ecological destruction caused by the indifference and surplus alienation of the masses. Then perhaps this will open the way to new, less destructive, less life-threatening and less alienating modes of dealing both with our newly found condition of ontologicalpolitical, geological forces acting into nature, and with its consequence, the socio-political and environmental ecological crisis.

\section{References}

AGAMBEN, Giorgio. Homo Sacer: Sovereign Power and Bare Life. Stanford: Stanford University Press, 1998.

AGAMBEN, Giorgio. Potentialities. Stanford, CA: Stanford University Press, 2000.

AGAMBEN, Giorgio. The Open: Man and Animal. Stanford: Stanford University Press, 2012.

ARENDT, Hannah. The Human Condition. Chicago: University of Chicago Press, 1959.

ARENDT, Hannah. Letter of Reply to Ralph Ellison, 1965. Disponivel em: http://memory.loc.gov/ cgi-bin/ampage?collld=mharendt_pub\&fileNa$\mathrm{me}=02 / 020340 / 020340$ page $\cdot \mathrm{db} \& \mathrm{recNum}=6 \& \mathrm{i}-$ temLink=/ammem/arendthtml/mharendtFolderPo2. html\&linkText=7. Acesso em: 19 maio 2020

ARENDT, Hannah. Crisis of the Republic. New York: Harcourt Brace \& Company, 1972

ARENDT, Hannah. The Origins of Totalitarianism. New edition with added prefaces. New York: Harcourt Brace Jovanovich, 1973 
ARENDT, Hannah. Thinking. In: ARENDT, Hannah. The Life of the Mind. One Volume Edition. New York: Harcourt, Inc., 1978a.

ARENDT, Hannah. The Life of the Mind. One Volume Edition. New York: Harcourt, Inc., 1978b.

ARENDT, Hannah. Lectures on Kant's Political Philosophy. Chicago: University of Chicago Press, 1982.

ARENDT, Hannah. Essays in Understanding: 1930-1954 Formation, Exile, and Totalitarianism. New York: Schocken Books, 1994

ARENDT, Hannah. Responsibility and Judgment. New York: Schocken Books, 2003.

ARENDT, Hannah. The Promise of Politics. New York: Schocken Books, 2005.

ARENDT, Hannah. Between Past and Future: Eight Exercises in Political Thought. New York: Penguin Books, 2006a.

ARENDT, Hannah. Eichmann in Jerusalem: A Report on the Banality of Evil. London: Penguin Books, 2006b.

ARENDT, Hannah. Thinking Without a Banister: Essays in Understanding, 1953-1975. New York: Schocken Books, 2018.

ARENDT, Hannah; KOHN, Jerome. Responsibility and Judgment. New York: Schocken Books, 2003.

BACON, Francis. The New Organon. New York: Cambridge University Press, 2000.

BARNOSKY, Anthony D. et al. Has the Earth's sixth mass extinction already arrived? Nature, [S. l.], v. 471, n. 7336, p. 51-57, 2011. DOI: 10.1038/natureog678

BRUNO LATOUR. Down to Earth - Politics in the New Climatic Regime. Cambridge: Polity Press, 2018.

CASTANHEIRA, Nuno Pereira. Reflexões sobre Política e Ambiente com Arendt e Marx - Desenvolvimento: O Ponto Cego da Sustentabilidade. In: AFONSO, Filipa; PÉREZ, José Luís; PEREIRA, Lavínia; VARANDAS, Maria José: FERREIRA, Maria Luísa Ribeiro; ESCOBAR, Sandra; MARQUES, Viriato Soromenho (org.). Pensar para o Outro: desafios éticos contemporâneos, Homenagem a Cristina Beckert. Lisboa: Centro de Filosofia da Universidade de Lisboa, 2017. p. 269-280.

CLARK, Timothy. Ecocriticism on the Edge:The Anthropocene as a Threshold Concept. London; New Delhi; Sidney; New York: Bloomsbury Academic, 2015

CRUTZEN, Paul J. Geology of Mankind. Nature, [S. l.], v. 415, n. 6867, p. 23-23, 2002. DOI: 10.1038/415023a.

DEVELOPMENT, World Commission On Environment and. Our Common Future. Oxford; New York: Oxford University Press, 1987.

EHLERS, Eckart; KRAFFT, Thomas. Earth System Science in the Anthropocene. Berlin; Heidelberg; New York: Springer, 2006.

FERGUSON, Peter. The green economy agenda: business as usual or transformational discourse? Environmental Politics, v. 24, n. 1, p. 17-37, 2015. DOI: 10.1080/09644016.2014.919748.
FERRY, Luc. Entretien: Protéger l'espèce humaine contre elle-même. Revue des deux mondes, n. Octobre-Novembre, p. 75-79, 2007.

GLASER, M. B. Memo to Exxon Management About CO2 Greenhouse Effect. New Jersey, NY. Disponivel em: http://www.climatefiles.com/exxonmobil/1982-memo-to-exxon-management-about-co2-greenhouse-effect/. Acesso em: 19 maio 2020.

HARVEY, David. A Brief History of Neoliberalism. Oxford; New York: Oxford University Press, 2005.

HEIDEGGER, Martin. Being and Time. Oxford: Basil Blackwell, 1967.

HEIDEGGER, Martin. The Question Concerning Technology, and Other Essays. New York: Harper Collins, 1982.

HUSSERL, Edmund. Logical Investigations - Volume I. London: Routledge, 2001.

INFLUENCEMAP. Big Oil's Real Agenda on Climate Change. London. Disponivel em: https://influencemap. org/report/How-Big-Oil-Continues-to-Oppose-the-Paris-Agreement-38212275958aa21196dae3b76220bddc. Acesso em: 19 maio 2020.

JACOBS, R. P. W. M.; GRIFFITHS, M. H.; BRIGHT, P. E.; HOMER, J. B.; VAN OUDENHOVEN, J. A. C. M.; WALLER, J. The Greehouse Effect. The Hague. Disponivel em: http://www.climatefiles.com/shell/1988-shell-report-greenhouse/. Acesso em: 19 maio 2020

KANT, Immanuel. Critique of the Power of Judgment. Cambridge: Cambridge University Press, 2000.

KIRBY, Benjamin. Pentecostalism, economics, capitalism: putting the Protestant Ethic to work. Religion, [S. l.], v. 49, n. 4. p. 571-591, 2019. DOI: 10.1080/0048721X.2019.1573767.

KOVEL, Joel. The Enemy of Nature - The End of Capitalism or the End of the World? London; New York; Halifax; Winnipeg: Zed Books; Fernwood Publishing, 2007.

MALM, Andreas; HORNBORG, Alf. The geology of mankind? A critique of the Anthropocene narrative. The Anthropocene Review, [S. l.], v. 1, n. 1, p. 62-69, 2014 DOI: 10.1177/2053019613516291.

MARCUSE, Herbert. Towards a Critical Theory of Society. London; New York: Routledge, 2001.

NATIONS, The United. It's time we took a seat 'at your table': Guterres calls on world youth to keep leading climate emergency response. UN News, New York, 2019a. Disponivel em: https://news.un.org/en/ story/2019/06/1041111. Acesso em: 19 maio 2020.

NATIONS, The United. Report of the Secretary-General on the 2019 Climate Action Summit - The Way Forward in 2020. New York. Disponivel em: https://www.un.org/ en/climatechange/assets/pdf/cas_report_11_dec.pdf. Acesso em: 19 maio 2020.

NEGRI, Antonio. Insurgencies: Constituent Power and the Modern State. Minneapolis: University of Minnesota Press, 1999.

RAFFNS $\varnothing E$, Sverre. Philosophy of the Anthropocene: The Human Turn. London: Palgrave Macmillan UK, 2016. 
RICOEUR, Paul. Oneself as Another. Chicago: The University of Chicago Press, 1992.

RIPPLE, William J.; WOLF, Christopher; NEWSOME, Thomas M.; GALETTI, Mauro; ALAMGIR, Mohammed; CRIST, Eileen; MAHMOUD, Mahmoud I.; LAURANCE, William F. World scientists' warning to humanity: A second notice. BioScience, [S. l.], v. 67, n. 12, p. 1026-1028, 2017. DOI: 10.1093/biosci/bix125.

ROLSTON, Holmes. A New Environmental Ethics: The Next Millennium for Life on Earth. New York: Routledge, 2012.

STEFFEN, Will et al. Trajectories of the Earth System in the Anthropocene. Proceedings of the National Academy of Sciences, [S. l.], v. 115, n. 33, p. 8252-8259, 2018. DOI: 10.1073/pnas.1810141115

UNITED NATIONS. Back to our Common Future: Sustainable Development in the 21st Century. New York, 2012. Disponivel em: http://sustainabledevelopment.un.org/ content/documents/UN-DESA_Back_Common_Future_En.pdf. Acesso em: 19 maio 2020

UNITED NATIONS. The Millennium Development Goals Report. New York, 2015. Disponivel em: https://visit. un.org/millenniumgoals/2008highlevel/pdf/MDG_Report_2008_Addendum.pdf. Acesso em: 19 maio 2020.

UNITED NATIONS. Report of the Secretary-General on the 2019 Climate Action Summit The Way Forward in 2020. New York, 2019. Disponivel em: https://www.un.org/ en/climatechange/assets/pdf/cas_report_11_dec.pdf. Acesso em: 19 maio 2020.

UNMÜSSIG, Barbara; SACHS, Wolfgang; FATHEUER, Thomas. Critique of the Green Economy - Toward Social and Environmental Equity. Berlin: Heinrich Böll Stiftung, 2012.

WARREN, Robert Penn. Who Speaks for the Negro? New Haven and London: Yale University Press, 2014.

WEBER, Max. The Protestant Ethic and the Spirit of Capitalism. London; New York: Routledge, 2005.

\section{Nuno Pereira Castanheira ${ }^{1}$}

Pesquisador PNPD/CAPES - PPG em Filosofia - PUCRS / Researcher PNPD/CAPES - Graduate Program in Philosophy - PUCRS. Membro-associado CFUL - Centro de Filosofia da Universidade de Lisboa / Associated-member CFUL - Center of Philosophy University of Lisbon.

\section{Mailing address}

Nuno Pereira Castanheira

Pontificia Universidade Católica do Rio Grande do Sul

Av. Ipiranga, 6681

Partenon, 90619-900

Porto Alegre, RS, Brasil 